\title{
Enhancement Strategy of Prospective Students's Interest in Zakat and Waqf Management Program
}

\author{
Rodame Monitorir Napitupulu ${ }^{1}$, Sarmiana Batubara ${ }^{2}$, Fahrina Putri Sapna ${ }^{3}$ \\ E-mail : rodamenapitupulu@iain-padangsidimpuan.ac.id ${ }^{1}$, sarmiana@iain- \\ padangsidimpuan.ac.id ${ }^{2}$, fahrinasapna@gmail.com3 \\ 1,2,3Institut Agama Islam Negeri Padangsidimpuan \\ 1,2,3Jl. T. Rizal Nurdin Km. 4,5 Sihitang Kota Padangsidimpuan 22733
}

\begin{abstract}
Abstrak,
Program studi (Prodi) Manajemen Zakat dan Wakaf Fakultas Ekonomi dan Bisnis Islam (FEBI) IAIN Padangsidimpuan mengalami penurunan jumlah mahasiswa sejak tahun 2018 hingga tahun 2020. Sebagai program studi dengan bidang ilmu yang kini sedang tren secara nasional dan global seharusnya peminat semakin meningkat namun sebaliknya justru menurun. Oleh karena itu, tujuan penelitian ini adalah untuk menganalisis strategi peningkatan animo calon mahasiswa Prodi Manajemen Zakat dan Wakaf. Penelitian ini menggunakan pendekatan kualitatif deskriptif dimana jumlah informan adalah 333 orang yakni siswa SMA/SMU/SMK/MAN dan santri dari pondok pesantren di Kota Padangsidimpuan, Kabupaten Tapanuli Selatan dan kota/kabupaten lain sekitarnya. Hasil penelitian menunjukkan terdapat beberapa informasi akademik dan nonakademik yang harus ditambahkan pada berbagai media promosi yang ada. Media promosi yang harus dipertahankan adalah direct selling (website resmi), media sosial (Facebook, Instagram dan Youtube, iklan (brosur), personal selling (tim promosi ke sekolah-sekolah).
\end{abstract}

Kata Kunci: Manajemen Zakat dan Wakaf, Promosi, Strategi

\begin{abstract}
,
The program of Zakat and Waqf Management at the Faculty of Islamic Economics and Business IAIN Padangsidimpuan experienced a decline in the number of students from 2018 to 2020. As a study program with a field of science that is currently trending nationally and globally, there should be an increasing number of enthusiasts, but on the contrary actually decreased. Therefore, the purpose of this study was to analyze the strategy of increasing the interest of prospective students of the Zakat and Waqf Management Study Program. This study uses a descriptive qualitative approach where the number of informants is 333 people, namely senior high school students and students from Islamic boarding schools in Padangsidimpuan City, South Tapanuli Regency and other surrounding cities/regencies. The results of the study indicate that there is some academic and non-academic information that must be added to various existing promotional media. Promotional media that must be maintained are direct selling (official websites), social media (Facebook, Instagram and Youtube, advertisements (brochures), personal selling (promotion teams to schools).
\end{abstract}

Keywords: Zakat and Waqf Management, Promotion, Strategy 


\section{Enhancement Strategy of Prospective Students's Interest in Zakat and Waqf Management Program \\ Rodame Monitorir Napitupulu, dkk.}

\section{Introduction}

Programs in department have an important role in the development of an educational institution or college. In general, it can be described how the quality of a university is with the quality of the study program. That is, if the study program is of good or quality, it is marked by being nationally accredited by BAN PT. In the study program accreditation instrument 4.0 issued by BAN PT there is a special assessment of governance, governance and cooperation carried out by the study program (Materi Sosialisasi IAPS 4.o (27 Mei 2019) - Lembaga Layanan Pendidikan Tinggi Wilayah VIII, n.d.).

Currently there are 17 study programs named Zakat and Waqf Management and there is 1 study program named Zakat and Waqf, which are spread throughout Indonesia and have been accredited at BAN PT. The Zakat and Waqf Management Study Program at the Padangsidimpuan State Islamic Institute is the only study program with a scientific field of zakat and waqf management with an S.E. in North Sumatra with the "Good" category which is valid until 2026 in accordance with Decree No.613/SK/BAN-PT/Ak-PKP/S/II/2021. In addition, currently the government and various research and educational organizations/institutions are aggressively supporting the zakat and waqf movement nationally and internationally at the world zakat and waqf forum. This shows the potential for zakat and waqf management skills now and in the future. Data on the development of the accreditation of the Zakat and Waqf Management Study Program in Indonesia in 2021 can be seen in Table 1.

Table 1.

Data on Accreditation of Zakat and Waqf Management Study Programs in Indonesia in 2021

\begin{tabular}{|c|c|c|c|c|}
\hline \multirow[t]{2}{*}{ No. } & \multirow[t]{2}{*}{ Nama Institusi } & \multicolumn{3}{|c|}{ Akreditasi } \\
\hline & & Baik & B & $\mathrm{C}$ \\
\hline 1 & Institut .. Agama & $\mathrm{v}$ & & \\
\hline & Padangsidimpuan & & & \\
\hline 2 & IAIN Bengkulu & & $\mathrm{v}$ & \\
\hline 3 & Institut Agama Islam Negeri Batusangkar & & $\mathrm{v}$ & \\
\hline 4 & $\begin{array}{l}\text { Institut Ilmu Al-Qur`an (IIQ) Jakarta, } \\
\text { Jakarta Selatan }\end{array}$ & & $\mathrm{v}$ & \\
\hline 5 & $\begin{array}{l}\text { Sekolah Tinggi Agama } \\
\text { Tamiang }\end{array}$ & & & $\mathrm{v}$ \\
\hline 6 & Institut Agama Islam Negeri ParePare & $\mathrm{V}$ & & \\
\hline 7 & Institut Agama Islam Negeri Kudus & & $\mathrm{v}$ & \\
\hline 8 & Universitas Muhammadiyah Jakarta & & $\mathrm{v}$ & \\
\hline 9 & Institut Agama Islam Negeri Ponorogo & & $\mathrm{v}$ & \\
\hline 10 & IAIN Jember & & $\mathrm{V}$ & \\
\hline
\end{tabular}




\begin{tabular}{lll}
11 & Universitas Islam Negeri Sunan Ampel & v \\
\hline 12 & IAIN Purwokerto & v \\
\hline 13 & IAIN Palangkaraya & v \\
\hline 14 & IAIN Surakarta & v \\
\hline 15 & $\begin{array}{l}\text { Universitas Islam Negeri Raden Fatah } \\
\text { Palembang }\end{array}$ & $\mathrm{V}$ \\
\hline 16 & $\begin{array}{l}\text { Sekolah Tinggi Agama Islam Negeri } \\
\text { Kudus }\end{array}$ & $\mathrm{v}$ \\
\hline 17 & Institut Agama Islam Negeri Tulungagung & \\
\hline
\end{tabular}

Source: (Distribusi Peringkat, n.d.)

The problem is that since the last 3 years there has been a decrease in the number of students of the Zakat and Waqf Management Study Program where in the 2018/2019 academic year the number of new students was 12 people, the $2019 / 2020$ academic year decreased to 9 people then in 2020/2021 it decreased to 1 person. Trends in the number of registrants in the Zakat and Waqf Management Study Program, Faculty of Islamic Economics and Business, Padangsidimpuan State Islamic Institute (FEBI IAIN Padangsidimpuan) in the last 3 years with 3 registration routes can be seen in Figure 1.

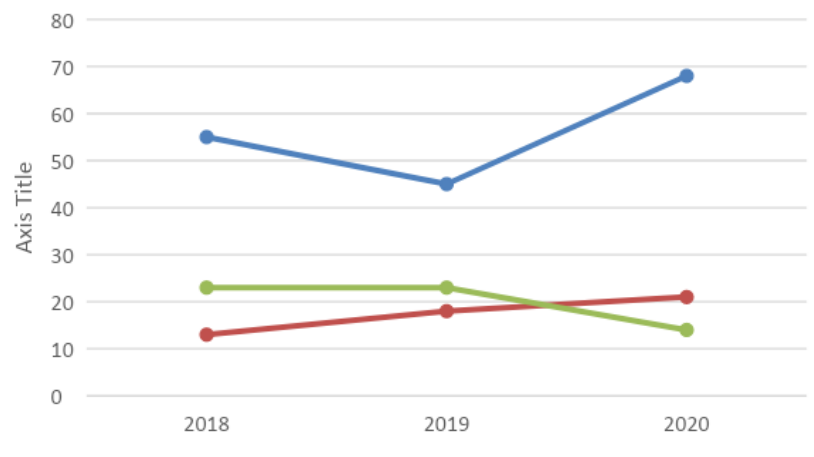

Figure 1.

Trends in Registration of Zakat and Waqf Management Study Programs in 2018-2020

Meanwhile, the number of registrants who passed decreased drastically from the number of registrants that had existed before. This decline in numbers can be expected because the screening process is strictly in accordance with the provisions that have been regulated at the institution and nationally. It can also be influenced by the scientific quality of the prospective students themselves.

In the digital era that uses the internet, it is very possible to introduce and increase the number of prospective students of the Zakat and Waqf Management Study Program. The use of website media is an effort to ensure the sustainability of a study program (Diantama, n.d.). The number of internet users in Indonesia is 


\section{Enhancement Strategy of Prospective Students's Interest in Zakat and Waqf Management Program Rodame Monitorir Napitupulu, dkk.}

currently very high, which as of November 2020 reached 196.7 million. Of the total internet users in Indonesia today, the majority are the young generation or what is now known as the millennial generation (generation $\mathrm{X}$, generation $\mathrm{Y}$, generation $\mathrm{Z}$ ). Dominated by the millennial generation in the age range of $15-19$ years as much as $91 \%, 20-24$ years as much as $88.5 \%, 25-29 \%$ as much as $82.7 \%, 30-34$ years as much as $76.5 \%$. This shows that the use of the website as a medium of communication and information will be very effective.

There are various online and offline promotional media that can be done by universities to increase the number of enthusiasts in various existing study programs. Padangsidimpuan State Islamic Institute conducts online promotions through social media such as: website, facebook, instagram, youtube. While offline promotions are carried out by directly visiting schools while distributing brochures. Plus promotions through advertisements on RAU 105 FM radio in Padangsidimpuan City. All these promotional strategies are carried out so that prospective students get information related to the Zakat and Waqf Management Study Program so that it can be spread to the wider community and even to foreign countries.

Website of the Faculty of Economics and Islamic Business with the link: http://febi.iain-padangsidimpuan.ac.id. In addition to the website, promotion through social media is also important. Social media plays an important role in the field of marketing services such as: tourism; education (Rifai, 2021). Utilization of social media in promoting thirst is optimized (Effendy, 2021). Currently, IAIN Padangsidimpuan and the Faculty of Economics and Islamic Business already have a variety of social media, however, there is no one focused on being managed by the Zakat and Waqf Management Study Program. This is something that needs to be considered considering the role of social media in promotion is very large. Therefore, the objectives of this study are: to analyze the level of knowledge of prospective students of the Zakat and Waqf Management Study Program towards the Zakat and Waqf Management Study Program; to analyze the interest of prospective students of the Zakat and Waqf Management Study Program towards the Zakat and Waqf Management Study Program and to develop promotional strategies recommended by prospective students of the Zakat and Waqf Management Study Program towards the Zakat and Waqf Management Study Program. 


\section{Literature Review}

Services themselves are different from goods, where services are intangible, heterogeneous, simultaneous production and consumption, perisable (Zeithaml \& Bitner, 2003). Services are products offered in abstract form (Soleh \& Said, 2019). Services are entities that do not have a form (Tjiptonon, 2019). Schools or universities (colleges) are institutions that sell information in the form of science and technology, which is why universities are included in the type of service. Both product and services have to be promoted well. There are various promotional media currently available. Technological advances have led to various paradigm shifts in promotion strategies. Digital technology has brought about changes in various aspects of people's lives, or the term is called digital transformation (Noor, 2021). Such significant changes are for example in terms of: targets, purchasing frequency, distribution channels, R \& D, driving factors, company orientation, public relations, communication, consumer behavior, quality, geographical coverage, type of communication, level of competition, production flow, type of communication media. and attractiveness (Rangkuti, 2013). Marketing through social media is now a trend or known as Social Media Marketing (Helianthusonfri, 2019). Social media is currently categorized into several platforms according to the type of content and its use (Prajarini, 2020), namely:

a. Social Networking is a social media that is used to communicate casually and privately where the goal is to build personal networks or certain groups. An example is Facebook.

b. Microblog is a platform that provides a text sharing feature where users can write anything like a blog but its characters are limited.

c. Video Sharing is a platform that is used to share videos where users can upload videos, edit videos, stream videos, and even live streams that are watched by people in various parts of the world. Examples are Youtube, Vimeo, Dailymotion and Tik Tok.

d. Professional Network Sharing is a platform that is commonly used to share professional networks, find work, advance career paths, internships, skills and other things that support work professionalism. The most famous platform is LinkedIn. 


\section{Enhancement Strategy of Prospective Students's Interest in Zakat and Waqf Management Program}

Rodame Monitorir Napitupulu, dkk.

e. Photo Sharing is a platform used to share photos where users can edit, use available effects or filters. This platform has special features in terms of visuals, where information can be presented in an attractive and easy-to-understand way. Examples of these platforms are Instagram and Snapchat.

f. Cooking is a platform commonly used to share recipe information by its users. These types of platforms include: Cookpad and Yummy App.

Some of the previous research studies that exist today include several similar study programs in Indonesia. The research entitled "Development of the Zakat and Waqf Management Study Program at the Sharia Faculty of IAIN Surakarta Based on Community Needs" shows that various efforts are needed in terms of HR, management of Study Programs and Facilities and Infrastructure (Hayatuddin, 2019). In another study entitled "Development of the Department of Zakat and Waqf at UIN SMH Banten" explained that the department of zakat and waqf deserves to be opened from FEBI, UIN SMH Banten because the interest of prospective students is quite good.

Other relevant research is related to the use of website media to increase the interest of prospective students, including a study entitled "The effectiveness of state university websites as information providers for students" which states that the website has indeed proven effective in efforts to convey information (Kriyantono, 2020) . In a study entitled "The Role of Social Media in Supporting the Performance and Popularity of Higher Education Institutions" where it is proven that the website has an effect on the performance and popularity of higher education institutions (Hafidhah et al., 2020). In a study entitled "Web-based Information Systems in the Implementation of Educational Institutions" it is stated that the use of websites in the provision of education is a demand for every existing educational unit (Laugi, 2018). In another study, the ease of use factor and the quality of service interaction on the university website had a significant effect on the satisfaction of users/web visitors (Napitupulu, 2017). Websites at universities are the main source of information by the public (Nadhiroh \& Kusumawati, 2015). Technology is proven to have an important role in education (Surani, 2019). Meanwhile, a case study in Timor Leste, a research linking the impact of the COVID-19 pandemic was carried out to find out what factors can improve the quality of university websites there where there needs to be an increase in web visibility (Wahyuningrum et al., 2021). 
Research analyzing websites at universities is also conducted at overseas universities in many countries. Some of them are research entitled "The Marketing of Higher Education Discourse: A Genre Analysis of University Homepages in China" which states that the presence of conversational features on the part of universities builds good relationships with prospective students (Zhang, 2017).

This is different in Australia, where universities in Australia have demonstrated a successful commitment to building website content/information that is relevant to the theme of sustainability in university management and operations at large (i.e., in general policies, company mission statements, research activities, available positions, and strategies) (Hasim et al., 2018). Meanwhile, the results of research related to visitor behavior at the eye university in Germany show that changes in website structure can affect the number of visitors and their behavior (Lang et al., 2020). In addition, it is proven that there is a relationship between website internal navigation and user experience design, usability and click through rate (Mombarg, 2021). In addition to utilizing the official website in marketing information related to higher education, currently educational institutions also use other social media such as Facebook and Instagram (Wijaya, 2020).

\section{Methods}

This research was conducted in Padangsidimpuan City and several other survey locations according to the list of survey locations that had been determined by previous researchers. Researchers collected research data on 12 SMA/SMK/MAN and Islamic Boarding Schools around the city of Padangsidimpuan directly. Meanwhile, for locations outside the city that have not been reached, google form assistance is used, which is distributed through existing social media networks such as Whatsapp. This research starts from August 2021 to November 2021. The research approach to the development of the zakat and waqf management study program is descriptive qualitative. Where the research informants are prospective students, namely Generation $\mathrm{Z}$ who are very dependent and understand in using the internet as well as the highest internet users in Indonesia. In this case are students who are in Public High Schools, Vocational High Schools and Islamic Boarding Schools in Padangsidimpuan City, South Tapanuli Regency and Panyabungan City and other cities bordering the southern part of Tapanuli. The subjects of this study were high 


\section{Enhancement Strategy of Prospective Students's Interest in Zakat and Waqf Management Program Rodame Monitorir Napitupulu, dkk.}

school, vocational, MA and Islamic boarding schools students who were prospective students of the Zakat and Waqf Management Study Program at FEBI IAIN Padangsidimpuan. Research subjects are also referred to as research informants (Rahardjo, 2017). Students are spread throughout the city of Padangsidimpuan and outside the city of Padangsidimpuan such as: South Tapanuli, Panyabungan, Batangtoru, South Tapanuli, Gunungtua, Batahan, Medan and other areas in North Sumatra. In this case, there were 12 school locations surveyed directly as shown in Table 2.

Table 2.

List of Research Subjects

\begin{tabular}{lll}
\hline $\begin{array}{l}\text { No } \\
\boldsymbol{*}\end{array}$ & Nama Sekolah & Lokasi \\
\hline $\mathbf{1}$ & SMK N 1 Padangsidimpuan & Dalam Kota \\
\hline $\mathbf{2}$ & SMA N 7 Padangsidimpuan & Dalam Kota \\
\hline 3 & MAS YPKS Padangsidimpuan & Dalam Kota \\
\hline 4 & Ponpes Darul Ikhlas Goti Padangsidimpuan & Dalam Kota \\
\hline 5 & MAN 1 Padangsidimpuan & Dalam Kota \\
\hline 6 & MAN 2 Padangsidimpuan & Dalam Kota \\
\hline 7 & SMK Swasta Kampus Padangsidimpuan & Dalam Kota \\
\hline 8 & SMA N 1 Sipriok & Luar Kota \\
\hline 9 & SMK LMC Model Industri Sipirok & Luar Kota \\
\hline 10 & SMA N 1 Panyabungan & Luar Kota \\
\hline 11 & Ponpes Al-Mandily Panyabungan & Luar Kota \\
\hline 12 & MAN 1 Panyabungan & Luar Kota \\
\hline
\end{tabular}

Data collection is done online through the website (Sarwono, 2006). Where in this case the researcher uses the help of the google form website. If interviews allow face-to-face meetings, face-to-face visits will be conducted by visiting the selected schools. Second, using an e-questionnaire by asking for student contact data from the school in distributing questionnaires via Whatsapp. Considering that we are still in a state of maintaining health protocols due to the COVID-19 pandemic. The type of interview used is a structured interview where all questions have been prepared by the researcher and answered in the order (Fadhallah, 2021). The data obtained will be tested for validity by testing credibility, namely checking data from various sources in various ways and at various times (Lestari \& Zakso, n.d.).

In this study, the analysis is divided into 2, where the first stage is descriptive analysis by tabulating the data obtained such as the characteristics of the informants, knowledge, interests and evaluation of promotions by the informants. Furthermore, 
the data is narrated and the relationship is seen by comparing information from various literatures that support the research results. The second stage, the results of the descriptive analysis that have been compared with relevant theories and literature are the basis for the formation of a strategy to increase the interest of prospective students of the Zakat and Waqf Management Study Program. The validity of qualitative research is an attempt to check the accuracy of research results by applying certain procedures while the reliability of qualitative research indicates that the approach used by researchers is consistent if applied by other researchers for different types of projects (Creswell, 2010). In this study, researchers tested the validity and reliability by checking the accuracy of the research results according to the existing stages. Data checking is done by examining evidence from research informants and using it to build a coherent justification (triangulation).

\section{Discussion}

\section{Description of Informant Characteristics}

Questionnaires made through google forms were then taken to schools that had been planned at the beginning of the study. Meanwhile, apart from going directly to the location and socializing the research instruments, the researchers also distributed to other schools what they got from existing friendship networks. This causes the electronic questionnaire to be more widely known by students in the city of Padangsidimpuan and its surroundings, even from outside the city. Therefore, the total informants in this study were 333 people.
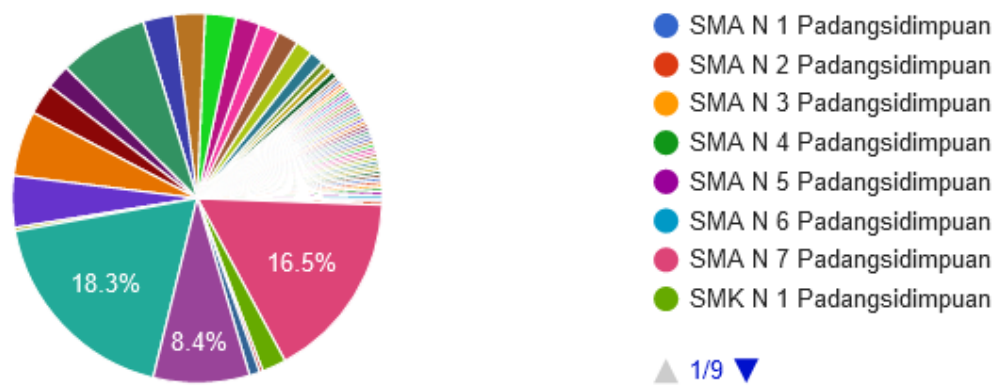

Figure 2.

\section{Informant's School of Origin}

Based on Figure 5, it is known that the majority of research informants came from Private Vocational Schools, Padangsidimpuan Campus, as many as 18.3\% or 61 people. Followed by students from SMA N 7 Padangsidimpuan City as many as $15.6 \%$ 


\section{Enhancement Strategy of Prospective Students's Interest in Zakat and Waqf Management Program}

Rodame Monitorir Napitupulu, dkk.

or 55 people. Furthermore, the third most came from SMA N Batangtoru 13.5\% or 45 people. The fourth highest came from Ponpes Darul Ikhlas Padangsidimpuan as many as $9.9 \%$ or 33 people. MAN 2 Padangsidimpuan City $8.4 \%$ or 28 people, MAN 1 Mandailing Natal $6.6 \%$ or 22 people. The rest are students from SMA N 1 Sipirok 5.7\% (19 people), MA YPKS Padangsidimpuan 4.5\% (15 people), SMK Sipirok Industrial Model 2.7\% (9 people), SMK N 1 Padangsidimpuan 2.7\% (9 people), MAS Darul Mursyid 2.1\% (7 people), SMA N 1 Padangsidimpuan, SMA N 2 Padangsidimpuan, SMA N 3 Padangsidimpuan, SMA 4 Padangsidimpuan, SMA 5 Padangsidimpuan, SMA N 6 Padangsidimpuan, SMK N 1 Padangsidimpuan, SMK N 2 Padangsidimpuan, MAN 1 Tapanuli Tengah, Private Vocational School Panca Budi, SMA N 1 Panyabungan, Islamic Boarding School Al-Mandily Panyabungan, SMA N 1 Batahan, Private High School Jabal Thoriq, SMK N 1 Lubuk Barumun, SMK N Bandar Pasir Mandoge and MAS Tahfidzhul North Sumatran Quran.

\section{Informant Knowledge}

The informant's knowledge starts from his knowledge of the existence of IAIN Padangsidimpuan. In this case, because the Zakat and Waqf Management Study Program is under the Faculty of Islamic Economics and Business (FEBI) where FEBI is under the auspices of the institute, knowledge regarding the presence of IAIN Padangsidimpuan is important to question. Of the total informants, 333 prospective students of the Zakat and Waqf Management Study Program knew about the existence of IAIN Padangsidimpuan. Meanwhile, the remaining 8.1 percent or 27 people did not know the existence of IAIN Padangsidimpuan. This shows that, the majority of research informants know the existence of IAIN Padangsidimpuan as many as 303 people (91.9\%).

Unfortunately, more than half of the total informants (333 people) were not aware of the existence of the Islamic Economics and Business Faculty (FEBI). In other words, $54.1 \%$ of informants or 180 people did not know FEBI. Meanwhile, only $45.9 \%$ or 153 people know about the existence of FEBI. This shows that there are still many prospective students of the Zakat and Waqf Management Study Program who do not know about the existence of FEBI in Padangsidimpuan.

Regarding the informant's knowledge about the existence of the Zakat and Waqf Management Study Program showed that the majority of students do not know 
the existence of the Zakat and Waqf Management Study Program. The number of students who did not know were 219 people (65.8 \%). Meanwhile, those who know about the existence of the Zakat and Waqf Management Study Program are only $34.2 \%$ or 114 people. This shows that the Zakat and Waqf Management Study Program is indeed unknown or unknown to most students both in Padangsidimpuan City and outside Padangsidimpuan City. Though knowledge affects a person's decision making. This is supported by several studies which state that knowledge has a positive effect on decisions to choose majors or study programs at universities (Budiarso et al., 2015; Rahman et al., 2019).
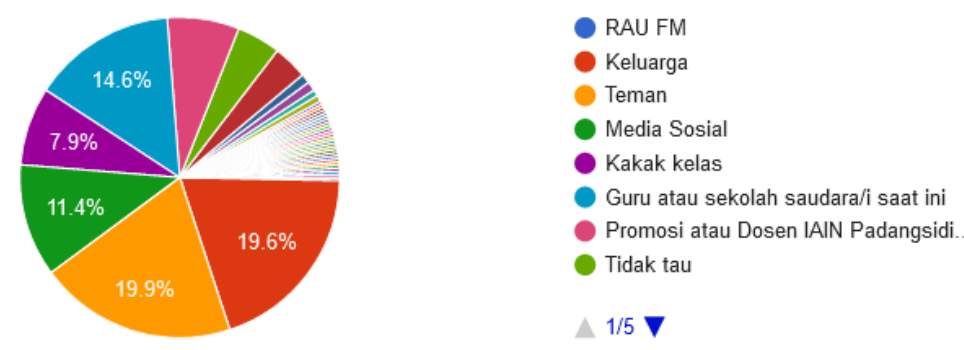

Figure 3.

Sources of Information on the Existence of IAIN Padangsidimpuan, Faculty of Economics and Islamic Business and Study Program of Zakat and Waqf Management

Based on Figure 3, it can be seen that the majority answered sources of information about the existence of the Zakat and Waqf Management Study Program are friends (19.9\%), followed by other sources of information such as: family (19.6\%), teachers/schools (14.6\% ), social media (11.4\%), seniors (7.9\%), promotions/lecturers of IAIN Padangsidimpuan (7.3\%). This shows that friends and family are the most effective providers of information according to prospective students of the Zakat and Waqf Management Study Program. Friends do play an important role in decision making. This is supported by several studies where friends influence the decision making to choose a major in higher education (Hernita, 2019; Sawaji et al., 2010).

\section{Informant Interest}

Students who are already in grade 12 must have thought about where to continue after finishing. Based on Figure 14, it is known that the majority of research informants want to continue to higher education after graduating from school. Where as many as $79.9 \%$ or 266 people intend to improve their knowledge at a higher level. The remaining $20.1 \%$ or 67 people are actually not interested in continuing their 


\section{Enhancement Strategy of Prospective Students's Interest in Zakat and Waqf Management Program Rodame Monitorir Napitupulu, dkk.}

studies. Furthermore, research informants who are prospective students of the Zakat and Waqf Management Study Program were asked about their interest in continuing their studies at the Zakat and Waqf Management Study Program FEBI IAIN Padangsidimpuan. The results show that the majority do not want to continue to the Zakat and Waqf Management Study Program where as many as $83.8 \%$ or 279 people are not interested in studying in the Zakat and Waqf Management Study Program. The rest, $16.2 \%$ or 54 people are interested in continuing their studies at the Zakat and Waqf Management Study Program.

The reasons why students don't want to continue their studies to the Zakat and Waqf Management Study Program are quite diverse. Based on Figure 12, it can be seen that the majority, namely 243 people (73\%) are not interested in continuing their studies to the Zakat and Waqf Management Study Program for personal reasons. Followed by family reasons by $9 \%$ (30 people). The rest are there for reasons of friends, social status reasons, economic reasons and other reasons. Based on this, it can be interpreted that there are many factors that influence a person's decision making. Personal reasons such as self-motivation have an influence on interest in becoming an Islamic college student (Fitriya \& Yani, 2014).

\section{Promotion Strategy of Zakat and Waqf Management Study Program}

So far, FEBI which oversees the Zakat and Waqf Management Study Program has done various things in promoting the Zakat and Waqf Management Study Program. However, the assessment can certainly vary from the student's own point of view. Therefore, it is important to know and get input from informants regarding the best and most appropriate promotional media to increase the interest of prospective students of the Zakat and Waqf Management Study Program (see Figure 4).
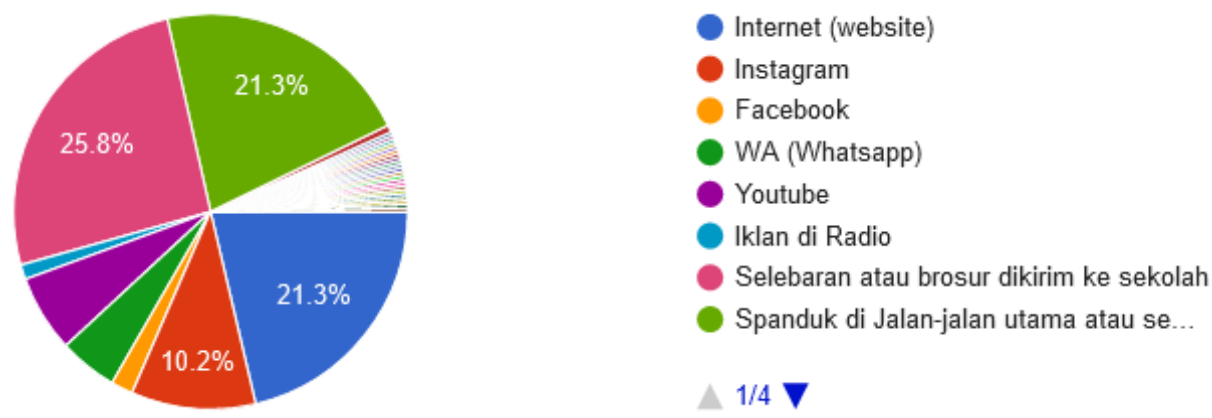

Figure 4. Informant Recommended Promotional Media 
Based on Figure 4, it can be seen that there are three promotional media that are highly recommended by prospective students of the Zakat and Waqf Management Study Program. The majority recommended promotion through leaflets or brochures sent to high schools or the equivalent in Padangsidimpuan City and outside Padangsidimpuan City where as many as 86 people or $25.8 \%$ agreed to recommend the promotional media. The existence of the FEBI website was already known to many informants. As many as $83.8 \%$ or 279 people have been aware of the FEBI official website. However, there are still as many as $16.2 \%$ or 54 students who do not know the existence of the FEBI official website. This shows that so far, the FEBI page has been known by the majority of informants. The page in question is http://febi.iain-padangsidimpuan.ac.id/program-studi-manajemen-zakat-wakaf/ where there is a special page for the Zakat and Waqf Management Study Program. This result is also supported by several studies which state that university websites play an important role as information providers (Kriyantono, 2020). Furthermore, in the research, it is stated that it is also necessary to pay attention to the elements in the website such as: honesty, interaction, affordability, availability of useful information, website maturity, usefulness, openness and positive values. In other studies, it is also said that the use of websites significantly affects the positive image of universities (Apriananta \& Wijaya, 2018).

The majority of informants do not know the existence of FEBI Instagram social media (@febiiain) with the following link: https://www.instagram.com/febiiain/. A total of 270 people or $81.1 \%$ of informants did not know about the existence of the FEBI Instagram account. Meanwhile, only $18.9 \%$ or 63 people know the existence of FEBI's Instagram social media. This shows that the use of Instagram social media has not been maximized. Even though the Instagram content of universities or colleges has an effect on the reputation of the university (Ardiansyah, 2021). Where it is also mentioned that a good reputation will affect student loyalty.

In addition, as many as 238 people or $71.8 \%$ of research informants answered that they did not know about the existence of FEBI's Facebook social media. This means that the majority of prospective students of the Zakat and Waqf Management Study Program are not familiar with the Facebook social media. The rest, as many as 


\section{Enhancement Strategy of Prospective Students's Interest in Zakat and Waqf Management Program Rodame Monitorir Napitupulu, dkk.}

$28.5 \%$ or 95 people know the existence of the FEBI Facebook social media which is located at the following link: https://www.facebook.com/Febi-IainPadangsidimpuan-478461805839041/. Facebook is known as a social media that plays an important role in online product marketing (Helianthusonfri, 2019). In addition, Facebook pages or known as fanpages also have the advantage of being able to reach large audiences from thousands to millions of people. That is why the use of social media Facebook can be useful for increasing popularity, including a university or college. Wilanda in a book entitled "Marketing and Social Media" mentions that Facebook is a social media platform with the third highest activity after Youtube and Whatsapp (Halim et al., 2020).

Next is related to other social media, namely Youtube. FEBI has a Youtube account that is used to share videos which also aims to promote various activities and existing facilities. Based on Figure 23, it is known that the majority of 251 people (76.1\%) informants do not know the existence of Youtube FEBI. The rest, $23.9 \%$ or 79 people know the existence of the FEBI Youtube social media. This shows that the FEBI Youtube social media is still not well known by candidates for the Zakat and Waqf Management Study Program. Whereas Youtube is highly recommended as a marketing medium (Eagle, 2019). Youtube is a social media platform that has an important role in decision making (Ramadhayanti, 2019).

Furthermore, it is related to the existence of brochures as promotional media to advertise the Zakat and Waqf Management Study Program. Based on Figure 24, it can be seen that the majority of research informants or as many as $92.2 \%$ (307 people) never received a brochure. While the remaining 7.8 (26 people) \% assessed that they had received brochures so that they knew the existence of the Zakat and Waqf Management Study Program.

In 2019, the Faculty of Islamic Economics and Business once printed brochures for promotional media and delivered them to high schools and the equivalent in Padangsidimpuan City and its surroundings. Brochure is one of the print media for promotion that is still widely used today. Brochures as educational media are considered effective for increasing knowledge (Nafiah \& Jumino, 2019). Promotion through brochures can increase public awareness so as to increase the number of students (Kusumo, 2018). 
Radio advertisements have been carried out for the last 2 years, but no evaluation has been carried out to see their effect on increasing the interest of prospective students of the Zakat and Waqf Management Study Program. Based on Figure 26, it is known that the majority of students have never heard of the advertisement of the Zakat and Waqf Management Study Program on RAU FM radio. Where as many as $88.9 \%$ (296 people) of the total informants said they never knew about the existence of the advertisement. Meanwhile, only $11.1 \%$ or 37 people are aware of the existence of advertisements on radio through RAU FM. RAU 105 FM is one of the most popular FM radio channels in Padangsidimpuan City and its surroundings. In addition, good relations and cooperation with RAU FM have also been carried out which have also supported the progress of IAIN Padangsidimpuan. However, in terms of promotion of the Zakat and Waqf Management Study Program, it has not yet had an impact on increasing prospective students of the Zakat and Waqf Management Study Program. Radio is one of the electronic promotional media that is still in demand by the public. Radio is not only available in big cities but is also available to areas and even reaches villages. That is why there are still many companies and service providers using radio for promotional purposes. This is also done by educational institutions that use radio as one of their marketing strategies (Yunitasari, 2019).

\section{Mapping the Strategy to Increase the Interest of Prospective Students of the Zakat and Waqf Management Study Program}

Based on the results of the descriptive analysis above, recommendations are made regarding various things that must be improved or improved or that must be done so that the interest of prospective students of the Zakat and Waqf Management Study Program increases as well. Furthermore, research informants also convey various information that must be conveyed when promoting the Zakat and Waqf Management Study Program through various types of promotions that already exist. Among them are according to those in Table 3. 


\section{Enhancement Strategy of Prospective Students's Interest in Zakat and Waqf Management Program}

Rodame Monitorir Napitupulu, dkk.

Table 3.

Information to Add

\begin{tabular}{lll}
\hline No. & \multicolumn{1}{c}{ Academic Information } & Nonacademic Information \\
\hline 1 & Tuition fee & Facilities/Amenities \\
\hline 2 & Scholarship & Video of University Condition \\
\hline 3 & Programs & $\begin{array}{l}\text { Testimonial of success person } \\
\text { in zakat and waqf management } \\
\text { study program }\end{array}$ \\
\hline 4 & The Superiority & Achievement \\
\hline 5 & Work Prospective & \\
\hline 6 & Curriculum & \\
\hline 7 & Learning Process & \\
\hline
\end{tabular}

The strategy to increase the interest of prospective students of the Zakat and Waqf Management Study Program was then mapped, namely by comparing the results of the assessment of current research informants with input from informants arranged in the form of strategies according to the types of promotions currently available (see Table 4).

Table 4 .

Mapping the Strategy to Enhancement the Interest of Prospective Students of the Zakat and Waqf Management Study Program

\begin{tabular}{|c|c|c|c|}
\hline No. & Promotion Type & Existing Condition & Strategy \\
\hline \multirow[t]{2}{*}{1} & Direct Marketing: & & \\
\hline & Official Website & $\begin{array}{l}\text { Need to be optimized } \\
\text { Needs to be improved in terms } \\
\text { of: } \\
\text { (1) Information on how to get a } \\
\text { scholarship } \\
\text { (2) Lack of documentation } \\
\text { (3) The official website is } \\
\text { promoted more so that it is } \\
\text { better known }\end{array}$ & $\begin{array}{l}\text { Defend and adding } \\
\text { information related to } \\
\text { how to get scholarships, } \\
\text { documentation and } \\
\text { further promoting the } \\
\text { official website in } \\
\text { various existing } \\
\text { promotional media }\end{array}$ \\
\hline \multirow[t]{4}{*}{2} & Media Sosial: & & \\
\hline & Facebook & $\begin{array}{l}\text { Need to be optimized } \\
\text { Needs to be improved in terms } \\
\text { of: } \\
\text { (1) Display } \\
\text { (2) Posts } \\
\text { (3) Facebook account needs to } \\
\text { be promoted more }\end{array}$ & $\begin{array}{l}\text { Defend and improve } \\
\text { overall in beautifying the } \\
\text { appearance, making } \\
\text { interesting posts and } \\
\text { updates and further } \\
\text { promoting it in various } \\
\text { existing promotional } \\
\text { media }\end{array}$ \\
\hline & Instagram & $\begin{array}{l}\text { Need to be optimized } \\
\text { Needs to be improved in terms }\end{array}$ & $\begin{array}{lr}\text { Defend and } & \text { overall } \\
\text { improvements } & \text { in }\end{array}$ \\
\hline & & $\begin{array}{lr}\text { of: } & \\
\text { (1) } & \text { Posting } \\
\text { pictures/information } & \text { on } \\
\text { activities or programs } & \end{array}$ & $\begin{array}{l}\text { beautifying the } \\
\text { appearance, posting } \\
\text { existing } \\
\text { activities/programs, }\end{array}$ \\
\hline
\end{tabular}




\begin{tabular}{|c|c|c|c|}
\hline & & $\begin{array}{l}\text { (2) Increase the number of } \\
\text { followers } \\
\text { (3) Instagram account needs } \\
\text { to be promoted more }\end{array}$ & $\begin{array}{l}\text { increasing followers by } \\
\text { promoting them more in } \\
\text { various existing } \\
\text { promotional media }\end{array}$ \\
\hline & Youtube & $\begin{array}{l}\text { Need to be optimized } \\
\text { Needs to be improved in terms } \\
\text { of: } \\
\text { (1) Increase the number of } \\
\text { videos } \\
\text { (2) Improve the quality of } \\
\text { uploaded videos } \\
\text { (3) Youtube account needs to } \\
\text { be promoted more }\end{array}$ & $\begin{array}{l}\text { Defend and increase } \\
\text { the number of videos, } \\
\text { upload videos of good } \\
\text { quality, create campus } \\
\text { atmosphere videos and } \\
\text { promote them more in } \\
\text { various existing } \\
\text { promotional media }\end{array}$ \\
\hline 3 & Advertising: & & \\
\hline & Brosur & $\begin{array}{l}\text { Need to be optimized } \\
\text { Needs to be improved in terms } \\
\text { of the pictures in the brochure } \\
\text { which are less and less } \\
\text { attractive }\end{array}$ & $\begin{array}{l}\text { Defend and improve } \\
\text { and add pictures } \\
\text { (activities/programs) of } \\
\text { study programs in the } \\
\text { brochure to make it } \\
\text { more interesting }\end{array}$ \\
\hline & Radio & $\begin{array}{l}\text { Need to be optimized } \\
\text { Needs to be improved in terms } \\
\text { of: } \\
\text { (1) Less creative } \\
\text { (2) Less easy to understand }\end{array}$ & $\begin{array}{l}\text { Reduced because the } \\
\text { majority never hear } \\
\text { broadcasts on the radio } \\
\text { again }\end{array}$ \\
\hline 4 & Personal Selling: & & \\
\hline & Promotion Team & $\begin{array}{l}\text { Need to be optimized } \\
\text { Needs to be improved in terms } \\
\text { of: } \\
\text { (1) Less friendly } \\
\text { (2) Lack of cohesiveness in the } \\
\text { promotion team } \\
\text { (3) Lack of detail in conveying } \\
\text { information }\end{array}$ & $\begin{array}{l}\text { Defend and improving } \\
\text { the ability of the } \\
\text { promotion team in } \\
\text { conveying information } \\
\text { can be done by } \\
\text { conducting a briefing } \\
\text { beforehand so that they } \\
\text { master the various } \\
\text { information submitted in } \\
\text { detail. }\end{array}$ \\
\hline
\end{tabular}

Based on this mapping, the strategy of increasing the interest of prospective students of the Zakat and Waqf Management Study Program becomes more focused according to the type of promotion that exists. Information that must be added in various promotional media includes: academic and non-academic fields. Information on academic fields that must be added is tuition fees per semester where the expected costs are affordable, scholarship programs and how to get them, various programs or activities (eg interest and talent development activities), advantages or advantages compared to other campuses, job prospects or job guarantees after graduation, course information and the learning process. Meanwhile, information on nonacademic fields that must be added is related to various existing facilities, videos of the atmosphere on campus, testimonials (real evidence) of someone's success in the field of zakat and waqf and their achievements. 


\section{Enhancement Strategy of Prospective Students's Interest in Zakat and Waqf Management Program}

Rodame Monitorir Napitupulu, dkk.

\section{Conclusion}

Based on the results of the study, it can be concluded that almost all types of promotional media have not been optimized. The majority of informants assessed that the current promotional strategy had not been conveyed properly due to the lack of promotion of various existing social media accounts. There are no social media accounts that are focused on being managed by the Zakat and Waqf Management Study Program, which also needs attention. Some of the media that can be maintained are Direct Marketing through the website; Social media namely: Facebook, Instagram, Youtube; Personal Selling through the presence of the promotion team to schools. Meanwhile, advertisements on radio were considered to be of no benefit because the majority had not listened to the radio, but the brochures distributed to schools had to be maintained and improved because they were highly recommended by students. Another additional promotional media suggested by students is the presence of banners on main streets or in schools. Meanwhile, the information that must be added in various promotional media includes: academic and non-academic fields. Information on academic fields that must be added is tuition fees per semester, scholarship programs and how to get them, programs or activities (eg interest and talent development activities), advantages compared to other campuses, job prospects after graduation, information on courses and learning processes. Meanwhile, information on non-academic fields that must be added are facilities, videos of the atmosphere on campus, testimonials of someone's success in the field of zakat and waqf and their achievements. Some suggestions that can be submitted to the Study Program Management Unit or the Faculty of Islamic Economics and Business are the need to optimize all types of promotions, both official websites, social media (Facebook, Instagram, Youtube) and advertisements through brochures distributed in schools. Meanwhile, the suggestion for the Zakat and Waqf Management Study Program is to add various information suggested by students, both academic and non-academic. There needs to be special social media management with social media accounts for the Zakat and Waqf Management Study Program FEBI IAIN Padangsidimpuan because until now there has never been one. 


\section{References}

Apriananta, Y. J., \& Wijaya, L. S. (2018). Penggunaan website dan media sosial dalam membangun citra positif perguruan tinggi. Komunikatif, 7(2), 187-209.

Ardiansyah, M. (2021). Analisis Peran Konten Instagram Universitas dan Loyalitas Mahasiswa terhadap Peningkatan Reputasi Universitas Kota Batam. Edumatic: Jurnal Pendidikan Informatika, 5(1), 50-59. https://doi.org/10.29408/edumatic.v5i1.3291

Budiarso, N. S., Wullur, M., \& Dotulong, L. O. (2015). Pengaruh Persepsi, Motivasi, Pengetahuan Akuntansi, Jangka Waktu Studi Terhadap Minat Melanjutkan Studi Pada Program Pendidikan Profesi Akuntansi. Jurnal Riset Akuntansi Dan Auditing GOODWILL, 6(2).

Creswell, J. W. (2010). Research Design: Pendekatan Kualitatif, Kuantatif dan Mixed (3rd ed.). Pustaka Pelajar.

Diantama, A. |. (n.d.). Upaya-Upaya Menjamin Keberlanjutan Program Studi Manajemen | Department of Management. Retrieved March 30, 2021, from http://manajemen.feb.unib.ac.id/upaya-upaya-menjamin-keberlanjutanprogram-studi-manajemen/, http://manajemen.feb.unib.ac.id/upaya-upayamenjamin-keberlanjutan-program-studi-manajemen/

Distribusi Peringkat. (n.d.). Badan Akreditasi Nasional Perguruan Tinggi. Retrieved June 16, 2021, from https://www.banpt.or.id/?page_id=1903

Eagle, W. (2019). YouTube Marketing For Dummies. John Wiley \& Sons.

Effendy, M. L. (2021). Pengaruh Strategi Promosi Melalui Media Sosial, Kualitas Pelayanan, Dan Word Of Mouth Terhadap Loyalitas Pelanggan Pada Warung Kopi Cak Kebo [PhD Thesis]. Universitas Muhammadiyah Jember.

Fadhallah, R. A. (2021). Wawancara. UNJ PRESS.

Fitriya, H., \& Yani, E. A. (2014). Faktor-Faktor yang Mempengaruhi Minat Mahasiswa Memilih Perguruan Tinggi Ekonomi Islam (Srudi Kasus: STEI SEBI). Jurnal Ekonomi dan Perbankan Syariah, 2(1), 99-130. https://doi.org/10.46899/jeps.v2i1.144

Hafidhah, H., Herli, M., \& Arifin, M. (2020). Peran Media Sosial dalam Menunjang Kinerja dan Popularitas Institusi Perguruan Tinggi. Jurnal Serambi Ilmu, 21(1), 1-17.

Halim, F. H., Sherly, \& Sudirman, A. (2020). Marketing dan Media Sosial. Media Sains Indonesia. 


\section{Enhancement Strategy of Prospective Students's Interest in Zakat and Waqf Management Program}

Rodame Monitorir Napitupulu, dkk.

Hasim, M. S., Hashim, A. E., Ariff, N. R. M., Sapeciay, Z., \& Abdullah, A. S. (2018). Commitment to sustainability: A content analysis of website for university organisations. IOP Conference Series: Earth and Environmental Science, 117, 012046. https://doi.org/10.1088/1755-1315/117/1/012046

Hayatuddin, A. K. (2019). Pengembangan Program Studi Manajemen Zakat dan Wakaf Fakultas Syariah IAIN Surakarta Berbasis Kebutuhan Masyarakat. ZISWAF: Jurnal Zakat Dan Wakaf, 6(2), 183-203.

Helianthusonfri, J. (2019). Belajar Social Media Marketing. Elex media komputindo.

Hernita, N. (2019). Pengaruh Teman Sebaya Dan Lingkungan Keluarga Terhadap Pengambilan Keputusan Dalam Memilih Jurusan. Eco-Iqtishodi: Jurnal Ilmiah Ekonomi Dan Keuangan Syariah, 1(1), 35-44.

Kriyantono, R. (2020). Efektivitas website perguruan tinggi negeri sebagai penyedia informasi bagi mahasiswa. Jurnal Studi Komunikasi, 4(1), 117-142.

Kusumo, H. (2018). Pemanfaatan Brosur sebagai Media Promosi untuk Meningkatkan Jumlah Peserta Didik pada Duta Islamic School (DIS) Semarang. Jurnal Nusantara Aplikasi Manajemen Bisnis, 3(1), 88-94.

Laugi, S. (2018). Sistem Informasi berbasis Web dalam Penyelenggaran Lembaga Pendidikan. Shautut Tarbiyah, 24(1), 109-126.

Lestari, M., \& Zakso, A. (n.d.). Faktor-Faktor Penyebab Rendahnya Minat Melanjutkan Pendidikan ke Perguruan Tinggi (Kasus pada Remaja di Desa Sepadu). 8.

Materi Sosialisasi IAPS 4.0 (27 Mei 2019) - Lembaga Layanan Pendidikan Tinggi Wilayah VIII. (n.d.). Retrieved June 16, 2021, from https://lldikti8.ristekdikti.go.id/2019/05/27/materi-sosialisasi-iaps-4-o-27mi-2019/

Mombarg, J. (2021, March 11). Usability and user experience design analysis on a University website: A usability and user experience of an internationally oriented university website; explaining the different click through rates of different studies [Info:eu-repo/semantics/masterThesis]. University of Twente. http://essay.utwente.nl/85946/

Nadhiroh, R., \& Kusumawati, D. (2015). Peran Website, Facebook dan Twitter Resmi UNS dalam Membangun Image Positif dan Meningkatkan Reputasi UNS. Surakarta: Universitas Sebelas Maret.

Nafiah, S., \& Jumino, J. (2019). Efektivitas Brosur Sebagai Media Pendidikan Pemakai Untuk Meningkatkan Pengetahuan tentang Perpustakaan di SMA Negeri 3 Semarang. Jurnal Ilmu Perpustakaan, 8(4), 249-259.

Napitupulu, D. (2017). Analysis of Factors Affecting The Website Quality (Study Case: XYZ University). International Journal on Advanced Science, Engineering 
$\begin{array}{llll}\text { and } \quad \text { Information } & \text { Technology, } & 7(3), & 792 .\end{array}$ https://doi.org/10.18517/ijaseit.7.3.1748

Noor, Z. Z. (2021). Buku Referensi Strategi Pemasaran 5.o. Deepublish.

Prajarini, D. (2020). Media Sosial Periklanan-Instagram. Deepublish.

Rahman, A., Karsudjono, A., \& Najmi, L. (2019). Pengaruh Pengetahuan, Dukungan Keluarga, dan Minat Mahasiswa terhadap Keputusan Mahasiswa dalam Memilih Kuliah di Jurusan Akuntansi pada Sekolah Tinggi Ilmu Ekonomi (STIE) Pancasetia Banjarmasin. Jurnal Mitra Manajemen, 3(9), 918-931.

Ramadhayanti, A. (2019). Strategi Pemasaran di YouTube Melalui Subscriber \& Komentar dan Perspektif Persuader Terhadap Keputusan Pembelian. Jurnal Manajemen Inovasi, 1O(1).

Rangkuti, F. (2013). Strategi Promosi yang Kreatif dan Analisis Kasus. Gramedia Pustaka Utama.

Rifai, A. (2021). Implementasi Manajemen Marketing Pendidikan Blue Ocean Strategy Melalui Pemanfaatan Media Sosial Dalam Meningkatkan Kuantitas Calon Peserta Didik Baru di Pondok Pesantren Abu Manshur [Diploma, IAIN Syekh Nurjati Cirebon]. http://web.syekhnurjati.ac.id

Sarwono, J. (2006). Strategi Penelitian di Internet. Graha Ilmu.

Sawaji, J., Hamzah, D., \& Taba, I. (2010). Pengambilan keputusan mahasiswa dalam memilih perguruan tinggi swasta di Sulawesi Selatan. E-Journal Program Pascasarjana Universitas Hasanuddin.

Soleh, M. Y., \& Said, M. (2019). Konsep dan Strategi Pemasaran: Marketing Concepts and Strategies. SAH MEDIA.

Surani, D. (2019). Studi literatur: Peran teknolog pendidikan dalam pendidikan 4.o. Prosiding Seminar Nasional Pendidikan FKIP, 2(1), 456-469.

Tjiptonon, U. S., Fandy. (2019). Strategi pemasaran dalam perspektif perilaku konsumen. PT Penerbit IPB Press.

Wahyuningrum, T., Kartiko, C., Wardhana, A. C., \& Soares, T. G. (2021). Revised web impact factor analysis of Timor Leste University website during COVID-19 pandemic. Bulletin of Electrical Engineering and Informatics, 10(3), 16781686. https://doi.org/10.11591/eei.v10i3.3034

Wijaya, D. G. (2020). Analisis Faktor-Faktor Yang Memengaruhi Minat Mahasiswa Berinfak Menggunakan Kitabisa. Com [PhD Thesis]. Universitas Brawijaya.

Yunitasari, D. (2019). Strategi promosi jasa pendidikan di sekolah dasar muhammadiyah terpadu (sdmt) ponorogo [PhD Thesis]. IAIN Ponorogo. 
Zeithaml, V. A., \& Bitner, M. J. (2003). Services Marketing: Integrating Custome Focus Across The Firm (Third). McGraw-Hill.

Zhang, T. (2017). The Marketization of Higher Education Discourse: A Genre Analysis of University Website Homepages in China. Higher Education Studies, 7(3), 64-79. 